Nutr Res. 2008 November ; 28(11): 809-810. doi:10.1016/j.nutres.2008.09.009.

\title{
Reply to J Cannell
}

Martha E. Payne, PhD, RD, MPH, John J. B. Anderson, PhD, and David C. Steffens, MD, MHS Department of Psychiatry and Behavioral Science and Neuropsychiatric Imaging Research Laboratory, Duke University Medical Center, Durham, NC and Department of Nutrition, The University of North Carolina at Chapel Hill, Chapel Hill, NC, USA

\section{Dear Editor}

We welcome the interest in our article, in which we reported a significant positive association between calcium and vitamin $\mathrm{D}$ intakes and brain lesions in older depressed patients and nondepressed comparison subjects [1]. However, concerns raised in the letter may be based upon inaccurate assumptions about our study. Many interpretations of our findings exist, but our results cannot be explained by dementia or institutional living.

Our sample included no one who was demented or living in an institution. As stated in the paper, we excluded individuals with significant cognitive impairment; including dementia based both on Mini-Mental State Examination score of less than 24 out of 30 and clinical evaluation by a geriatric psychiatrist. The presence of brain lesions is indeed a risk factor for dementia [2] but not a specific indicator for current dementia. Regarding place of residence, subjects in this study were community-dwelling older adults.

We applaud the discussion generated by our report and welcome the opportunity to clarify our research methodology. Our finding of an association between higher calcium and vitamin D intakes and brain lesions may strike some as counterintuitive but it is plausible and consistent with the potential role of calcium dysregulation in cerebrovascular disease. If calcium and vitamin $\mathrm{D}$ are found to be etiologically related to brain lesions, it is possible that only specific subsets of the population are at risk, as determined by such factors as renal functioning, cardiovascular risk profile, and genes. We hope that future research will help to clarify the roles of calcium and vitamin D in brain health. While this effort may be inconvenient to proponents of vitamin D supplementation, we believe that it is in the public's best interest to elucidate the potential benefits as well as the risks of all nutrients for people across the diet and health spectra.

\section{References}

1. Payne ME, Anderson JJB, Steffens DC. Calcium and vitamin D intakes may be positively associated with brain lesions in depressed and non-depressed elders. Nutr Res 2008;28:285-292. [PubMed: 19083421]

2. Vermeer SE, Prins ND, den Heijer T, Hofman A, Koudstaal PJ, Breteler MM. Silent brain infarcts and the risk of dementia and cognitive decline. N Engl J Med 2003;348:1215-22. [PubMed: 12660385]

E-mail: Martha.payne@duke.edu (ME Payne).

None of the authors had a conflict of interest.

Publisher's Disclaimer: This is a PDF file of an unedited manuscript that has been accepted for publication. As a service to our customers we are providing this early version of the manuscript. The manuscript will undergo copyediting, typesetting, and review of the resulting proof before it is published in its final citable form. Please note that during the production process errors may be discovered which could affect the content, and all legal disclaimers that apply to the journal pertain. 